KRZYSZTOF NYKIEL

Penitencjaria Apostolska Rzym

\title{
Penitencjaria Apostolska: Trybunał miłosierdzia w służbie Kościołowi
}

The Apostolic Penitentiary: Tribunal of Mercy at the Service of the Church

Celem niniejszego opracowania jest przedstawienie najstarszej: Dykasterii Kurii Rzymskiej, jaką jest Penitencjaria Apostolska, jej struktury, uprawnień, działalności, zilustrowanie zarówno jej metody codziennej pracy, jak i sposobu traktowania spraw sumienia, które $\mathrm{z}$ racji swego ciężaru są zarezerwowane dla Stolicy Apostolskiej. Nie jest znana precyzyjna data jej powstania, lecz na podstawie wiarygodnych źródeł historycznych wiadomo, że pod koniec XII wieku istniał urząd penitencjarza większego.

Penitencjaria Apostolska, pomimo swej długiej historii, jest mało znana, nawet $\mathrm{w}$ świecie kościelnym, głównie z racji natury swej działalności.

Jest to jeden z trybunałów Stolicy Apostolskiej wymieniony w Konstytucji Pastor bonus Jana Pawła II z 28 czerwca 1988 r. jako pierwszy wśród Trybunałów Stolicy Apostolskiej (Penitencjaria Apostolska, Sygnatura Apostolska, Rota Rzymska). Jej uprawnienia zostały określone w art. 117-120 wspomnianego dokumentu papieskiego i dotyczą wyłącznie forum wewnętrznego (sumienia), tzn. ukrytego obszaru osobistych, duchowych relacji między miłosiernym Bogiem a wiernym, penitentem. Forum wewnętrzne jest sakramentalne, jeśli ściśle związane jest z sakramentem pokuty, a pozasakramentalne, jeśli sprawy sumienia rozpatrywane są poza sakramentem spowiedzi. Penitencjaria Apostolska nie ma funkcji prawnych związanych z forum zewnętrznym, tak jak wspomniana Rota Rzymska czy Sygnatura Apostolska. Sprawuje jurysdykcję łaski.

Można słusznie powiedzieć, że wypełnia służbę wyłącznie duchową, to znaczy funkcję bezpośrednio związaną z celem misji Kościoła, jakim jest zbawienie ludzkiej duszy (salus animarum). 
$\mathrm{Na}$ forum wewnętrznym, zarówno sakramentalnym, jak i pozasakramentalnym, Penitencjaria Apostolska udziela „rozgrzeszeń”, „dyspens”, „łask”, „uważnień”, „zamian” oraz wielu innych łask. Do kompetencji Penitencjarii Apostolskiej należą także sprawy związane z udzielaniem i praktyką odpustów, z wyjątkiem kwestii dogmatycznych tych odpustów, które są zarezerwowane dla Kongregacji Nauki Wiary. Ponadto troszczy się, nawiązując do swych historycznych korzeni sięgających XII wieku, o zapewnienie w bazylikach patriarchalnych Rzymu wystarczającej liczby spowiedników, wyposażonych w odpowiednie upoważnienia. Penitencjaria Apostolska jest więc organem służącym spowiednikom i penitentom. Słusznie można ją nazwać Trybunałem Miłosierdzia, ponieważ jej główną misją jest pomaganie $\mathrm{w}$ procesie pojednania $\mathrm{z}$ Bogiem i z Kościołem wiernego, który znalazł się w sytuacji niedającej się pogodzić z jego wiecznym zbawieniem.

\section{STRUKTURA PENITENCJARII APOSTOLSKIEJ}

Penitencjaria Apostolska ma następującą strukturę:

- penitencjarz większy - Jego Eminencja ks. kard. Mauro Piacenza;

- regens - J.E. ks. Prałat Krzysztof Nykiel;

- Rada Kardynała Penitencjarza (w jej skład wchodzą regens i pięciu prałatów: teolog - o. Ján Ďačok SJ, kanonista - JE ks. bp Juan Ignacio Arrieta Ochoa de Chinchetru, trzej konsulatorzy - o. Maurizio Faggioni OFM, don Paolo Carlotti SDB, ks. prałat Giacomo Incitti;

- oficjałowie - codziennie wykonują różne zadania, jednak bez ograniczenia ich do zwykłej realizacji, w odróżnieniu od innych dykasterii; uczestniczą oni bowiem w codziennych sesjach (kongresach), na których przedstawiają swoje votum.

Po schematycznym przedstawieniu struktury Trybunału Penitencjarii Apostolskiej warto przybliżyć poszczególne funkcje i zadania osób pełniących posługę w tymże Trybunale Miłosierdzia.

\section{Kardynał penitencjarz większy}

Stoi on na czele Penitencjarii Apostolskiej i łączy w sobie wszystkie uprawnienia tej dykasterii. Trudno wymienić je wszystkie, bowiem jest czymś niezmiernie trudnym sporządzenie katalogu wszelakich spraw i przypadków, które mogą się pojawić. Niemniej jednak należy przypomnieć, że gdy idzie o uprawnienia Penitencjarii Apostolskiej, to zostały one potwierdzone przez papieża Benedykta XVI podczas audiencji udzielonej kardynałowi penitencjarzowi większemu, 16 czerwca 2005 roku$^{1}$ i w dalszym ciagu są obowiązujące. W konsekwencji,

\footnotetext{
${ }^{1}$ Por. Reskrypt ex Audientia SS.mi z dnia 16 czerwca 2005: „Penitencjaria Apostolska, aby móc wykonywać swoje zadania na forum wewnętrznym, posiada wszystkie konieczne uprawnie-
} 
Penitencjaria na forum wewnętrznym może traktować także sprawy, które rozpatrują na forum zewnętrznym inne Dykasterie Kurii Rzymskiej. Ewentualne skutki, jakie jej wykonywanie zdolne jest wywołać w zakresie zewnętrznym, nie są uznawane $\mathrm{w}$ tym zakresie, chyba że jest to postanowione w określonych przez prawo przypadkach (por. kan. $130 \mathrm{KPK}$ ).

Jeśli rozwiązanie problemów przekracza jej habitualne uprawnienia, Penitencjaria działa ex Audientia SS.mi, czyli po przedłożeniu konkretnego przypadku Ojcu Świętemu i otrzymaniu od niego koniecznego zezwolenia. Jak już wyżej powiedziano, kardynał penitencjarz większy, jest nim obecnie kard. Mauro Piacenza, łączy w sobie wszystkie uprawnienia Penitencjarii, które może wykonywać tylko po uprzedniej konsultacji ze swoimi współpracownikami. Osąd kardynała penitencjarza dotyczący danej sprawy może się różnić od votum współpracowników i gdy tak się dzieje, wówczas zostaje on zaprotokółowany.

Kardynał penitencjarz, któremu zwyczajowo towarzyszy regens, jest od czasu do czasu przyjmowany na audiencji przez Ojca Świętego i składa mu dokładne sprawozdanie z pracy i funkcjonowania Penitencjarii Apostolskiej.

W gestii penitencjarza większego leży ponadto nominacja i udzielenie uprawnień do spowiadania penitencjarzom zwyczajnym zwanym penitencjarzami mniejszymi bazylik papieskich Rzymu po zdaniu przez nich egzaminu-kolokwium wymaganego przez normy papieskie dla pełnienia przez nich takiego urzędu. Udziela także koniecznych uprawnień spowiednikom, tzw. nadzwyczajnym, współpracującym z penitencjarzami mniejszymi, według zaaprobowanego regulaminu. Innym zadaniem kardynała penitencjarza większego jest podpisywanie reskryptów, dekretów i dokumentów większej wagi, tak ze względu na materię, jak i na adresata, jak np. dekretów ogólnych, dekretów dotyczących odpustów czy reskryptów, które dają ostateczne rozwiązania w sprawach forum wewnętrznego.

Należy także podkreślić, że kardynał penitencjarz większy, z samej natury swoich zadań i funkcji, jaką jest troska o dobro dusz, nie traci swojego urzędu podczas wakatu Stolicy Apostolskiej. Ta norma po raz pierwszy ustanowiona przez Sobór w Vienne (1311-1312), znalazła potwierdzenie w art. 6 Konstytucji apostolskiej Pastor bonus. Dlatego też Penitencjaria Apostolska - zazwyczaj za pośrednictwem regensa - może, jeśli zachodzi taka konieczność, komunikować się z kardynałem penitencjarzem podczas trwającego konklawe.

\section{Regens Penitencjarii Apostolskiej}

Regens jest bezpośrednim i pierwszym współpracownikiem kardynała penitencjarza, jest - tak jak np. sekretarze w Kongregacjach Kurii Rzymskiej - prałatem wyższym. Jak wskazuje jego nazwa, jest tym, który kieruje Penitencjarią

nia, z wyjątkiem jedynie tych, które Ojciec Święty zakomunikował bezpośrednio Kardynałowi Penitencjarzowi, chcąc zarezerwować je sobie". 
Apostolską. Jest odpowiedzialny za jej organizację i właściwe funkcjonowanie, zawsze pod autorytetem władzy kardynała penitencjarza, którego także zastępuje w razie jego nieobecności. Wykonuje ponadto inne zadania, które są mu delegowane przez penitencjarza większego. Musi dysponować szczególnymi kompetencjami w zakresie prawa kanonicznego i teologii moralnej. Wśród wielu zadan, jakie na nim spoczywają, warto zwrócić uwagę na przewodniczenie codziennemu kongresowi, podczas którego rozpatrywane są sprawy, które napłynęły do Penitencjarii, a które wymagają natychmiastowego rozpatrzenia i dania odpowiedzi petentom z uwagi właśnie na zbawienie dusz.

\section{Rada Kardynała Penitencjarza}

Tak jak już wcześniej napisano, Rada Kardynała Penitencjarza, składa się z regensa i pięciu innych prałatów. Radni są konsultowani w różnych przypadkach, dając ich vota na piśmie lub pod przewodnictwem kardynała Penitencjarza, zbierają się na posiedzeniach tzw. „Sygnatury” (jest to instancja wyższa Penitencjarii Apostolskiej, będąca kongresem nadzwyczajnym, zwoływanym ilekroć zachodzi taka konieczność), by przedyskutować nowe, szczególnie trudne przypadki natury moralnej, etycznej czy prawnej, przedkładane Penitencjarii Apostolskiej z całego świata. W ten sposób wypracowuje się jak najbardziej klarowną odpowiedź, zgodną z nauczaniem Kościoła, osobie, która przedłożyła Penitencjarii dany przypadek osobiście lub poprzez swojego spowiednika. Na takim posiedzeniu mogą być też dyskutowane sprawy przedstawione $\mathrm{z}$ urzędu. Członkowie Rady mogą być także delegowani przez kardynała penitencjarza do reprezentowania Penitencjarii w różnych inicjatywach, w które jest zaangażowana Penitencjaria Apostolska.

\section{Inni oficjałowie}

Oficjałami Penitencjarii Apostolskiej są kapłani, którzy uczestniczą w codziennych kongresach, odbywających się pod przewodnictwem regensa w celu przebadania wpływających spraw. Proponują oni rozwiązania, które po aprobacie regensa przedstawiane są do decyzji i podpisu przez kardynała penitencjarza większego. Pod nieobecność kardynała penitencjarza reskrypt zawierający decyzje Penitencjarii Apostolskiej w konkretnej sprawie jest podpisywany przez regensa i kontrasygnowany przez jednego $z$ pozostałych oficjałów oraz jeśli to możliwe, w tym samym dniu (jest praktyką Trybunału odpowiadać proszącym w ciagu 24 godzin lub przynajmniej tak szybko, jak to możliwe; jeśli sprawa wymaga dłuższego studium, wówczas informuje się o tym petenta przez jego spowiednika), wysłany na adres wskazany przez osobę, która się zwróciła do Penitencjarii Apostolskiej, zazwyczaj jest to spowiednik. Może zdarzyć się tak, że nie ma jednomyślności na Kongresie. Jeśli jej nie ma - a takowa jest wymagana należy odnotować to w Protokole i przedstawić penitencjarzowi do jego decyzji. 
Jeśli kardynał penitencjarz uważa, że konkretny przypadek, na skutek dużej rozbieżności głosów, należałoby głębiej przestudiować, może poprosić o dodatkowe votum jednego czy dwóch prałatów należących do jego Rady lub zdecydować o zwołaniu posiedzenia rady, tzw. „Sygnatury” Penitencjarii Apostolskiej.

\section{MATERIE PODLEGAJĄCE KOMPETENCJI PENITENCJARII APOSTOLSKIEJ}

Chociaż obowiązujące dziś prawo kanoniczne ukształtowane jest głównie według zasad umiarkowania w karaniu i tzw. „decentralizacji”, to jednak niektóre przypadki (chodzi tu o przestępstwa karane cenzurami latae sententiae, kiedy podlega się karze automatycznie przez samo popełnienie tychże przestępstw [ipso facto], bez konieczności nałożenia jej w procesie kanonicznym lub dekretem, o czym mowa w Kodeksie Prawa Kanonicznego z 1983 r., lub o grzechy zastrzeżone, o których mowa w Kodeksie Kanonów Kościołów Wschodnich z 1991 r.) o szczególnym znaczeniu - ze względu na ich wagę albo na skutki, które moga za sobą pociągać - są zastrzeżone Stolicy Apostolskiej (tzn. na forum wewnętrznym Penitencjarii Apostolskiej), a mianowicie:

1. Wobec wiernych obrzqdku łacińskiego cenzury (ekskomunika) za następujace przestepstwa:

- profanacja świętych postaci konsekrowanych (por. Kodeks Prawa Kanonicznego = KPK, kan. 1367);

- bezpośrednie naruszenie tajemnicy spowiedzi (tamże, kan. 1388, §1);

- rozgrzeszenie wspólnika w grzechu przeciw szóstemu przykazaniu Dekalogu (tamże, kan. 1378, §1);

- zastosowanie przymusu fizycznego wobec biskupa Rzymu (tamże, kan. 1370);

- przyjęcie i udzielenie konsekracji biskupiej bez mandatu apostolskiego (tamże, kan. 1382);

- usiłowanie udzielenia święceń kobiecie (por. SST, art. 5, n. 1).

2. W odniesieniu do wiernych obrzqdków wschodnich:

- grzechy bezpośredniego naruszania tajemnicy spowiedzi;

- rozgrzeszenie wspólnika grzechu przeciwko szóstemu przykazaniu Dekalogu (Kodeks Kanonów Kościołów Wschodnich $=$ KKKW, kan.728, §1, nn. 1 i 2); należy tu jednak zaznaczyć, że zastrzeżenie to nie obowiązuje, gdy - według roztropnej oceny spowiednika - nie można poprosić (odnieść się do) kompetentnej władzy o upoważnienie do udzielania rozgrzeszenia bez poważnych kłopotów dla penitenta lub bez zagrożenia „zdrady" tajemnicy spowiedzi (tamże, kan. 729, nn. 1 i 2). 
Odnośnie do wiernych obrządku wschodniego na mocy kanonu $730 \mathrm{KKKW}$ i odnośnie do wiernych obrządku łacińskiego na mocy kanonu 977 KPK rozgrzeszenie wspólnika - poza niebezpieczeństwem śmierci - jest nieważne.

Aktualnie obowiązujące prawo kościelne przewiduje dziewięć przestępstw karanych ekskomuniką latae sententiae, a jedynie tych sześć wyżej wymienionych dotyczących wiernych obrządku łacińskiego jest zarezerwowanych Stolicy Apostolskiej. Dla wiernych obrządków wschodnich jest mowa o dwóch grzechach zarezerwowanych Stolicy Apostolskiej. Jeśli wyżej wymienione przestępstwa i grzechy zarezerwowane nie były przedmiotem wyroku sądowego lub nie zostały publicznie zdeklarowane, są rozpatrywane na forum wewnętrznym przez Penitencjarię Apostolską. Pozostałe przestępstwa karane cenzurami latae sententiae - pięć interdyktem i sześć suspensą, są zastrzeżone zwyczajnej władzy diecezjalnej lub wyższym przełożonym zakonnym wobec wiernych im podlegających.

Z wyżej wymienionych przestępstw na szczególną uwagę zasługuje profanacja świętych postaci konsekrowanych, bezpośrednie naruszenie tajemnicy spowiedzi i rozgrzeszenie wspólnika w grzechu przeciw szóstemu przykazaniu Dekalogu, ponieważ one najczęściej mają miejsce. W Kodeksie Kanonów Kościołów Wschodnich (=KKKW) nie mówi się o przestępstwach i o cenzurach latae sententiae z nimi związanymi, lecz o grzechach zastrzeżonych Stolicy Apostolskiej.

\section{Profanacja świętych postaci konsekrowanych}

W kan. 1367 (por. kan. 1442 KKKW, który przewiduje karę ekskomuniki większej i jeżeli sprawcą jest to osoba duchowna, także inne kary) prawodawca stanowi, że karze ekskomuniki latae sententiae podlega ten, kto postacie konsekrowane porzuca albo w celu świętokradczym zabiera lub przechowuje². Ekskomunikę w tym przypadku zdeklarować lub wymierzyć może tylko Stolica Apostolska i dlatego może być ona zdeklarowana i uchylona przez Penitencjarię Apostolską jako trybunał forum wewnętrznego lub przez Kongregację Nauki Wiary jako trybunał forum zewnętrznego ${ }^{3}$, a także przez każdego spowiednika w niebezpieczeństwie śmierci zagrażającemu sprawcy przez trybunał sakramentalny $z$ nałożeniem obowiązku na penitenta, w przypadku wyzdrowienia lub wyjścia z sytuacji zagrożenia, udania się do odpowiednich władz kościelnych. Przestępstwo to, niestety, dokonywane jest częściej, niż można to sobie wyobrazić. W niektórych przypadkach wierny dokonuje zbezczeszczenia potajemnie, na

${ }^{2}$ Zob. także: Pontificium Consilium de Legum Textibus Interpretandis, Responsio ad propositum dubium, 4.06.1999, AAS 91(1999) s. 918.

${ }^{3}$ Ioannes Paulus II, Constitutio apostolica Pastor bonus de Romana Curia, 28.06.1988, AAS 80(1988), s. 841-912, art. 52 i 118; Regolamento Generale della Curia Romana, Libreria Editrice Vaticana, 1999, art. 11. 
przykład w domu, w jakimś innym pomieszczeniu czy też na ulicy. Wiele z tych profanacji popełnionych zostaje podczas rytuałów satanistycznych, a sposoby ich popełnienia są różne, bo człowiek zdolny jest do dokonania nieprawdopodobnych rzeczy. Różne są też powody, które prowadzą do profanacji postaci konsekrowanych: czasem z nienawiści do Boga, czasami z zemsty lub ze względu na przesądy albo z nieopanowanych namiętności, zwłaszcza wyuzdania lub z zaburzeń psychicznych. Aby zapobiec tego typu przestępstwom, bardzo ważne jest, aby kapłani obserwowali, co czynią wierni, którzy otrzymują Komunię Świętą na rękę, tak by, gdy zorientują się, że ci wrócili na swoje miejsce bez spożycia Komunii, powinni podjać odpowiednie działania. Innymi słowy, trzeba zachować czujność, również na forum zewnętrznym, aby złu zapobiegać, denuncjować je i karać.

\section{Bezpośrednie naruszenie tajemnicy sakramentalnej}

Jest to przestępstwo, które może być popełnione tylko poprzez kapłana działającego jako spowiednik, nawet jeśli ostatecznie nie udzielił on rozgrzeszenia penitentowi.

Zgodnie z kan. $1388 \S 1$ spowiednik, który narusza bezpośrednio tajemnicę sakramentalną spowiedzi (sigillum sacramentale), podlega ekskomunice latae sententiae, z której uwolnienie jest zastrzeżone Stolicy Apostolskiej, jeśli zaś narusza ją tylko pośrednio, powinien być ukarany stosownie do wagi przestępstwa, czyli w trybie ferendae sententiae. Racją istnienia kary ekskomuniki jest ochrona świętości sakramentu pokuty, jedynego środka, poprzez który wierni otrzymują zwyczajnie przebaczenie grzechów i mają prawo gwarancji zachowania w tajemnicy tego, co wyznali podczas spowiedzi. Jakakolwiek wątpliwość w tym względzie mogłaby przyczynić się do odejścia od konfesjonału.

Obowiązek zachowania tajemnicy dotyczy także tłumacza, jeśli występuje, oraz osób, które w jakikolwiek sposób weszły w posiadanie wiadomości o grzechach (por. kan. 983). Mamy do czynienia z bezpośrednim naruszeniem tajemnicy sakramentalnej spowiedzi, jeśli spowiednik umyślnie (ex dolo) wyjawiłby tożsamość penitenta i grzechy penitenta, usłyszane podczas spowiedzi, przy czym wystarczy niekiedy dokładny ich opis, by się domyśleć, o kogo i o jaki grzech chodzi. Stąd też potrzeba ogromnej czujności i roztropności. Nienaruszalność tajemnicy spowiedzi nie dopuszcza żadnych wyjątków ani dyspens. Obowiązuje spowiednika nawet po śmierci penitenta. Karze ekskomuniki latae sententiae za zdradę tajemnicy sakramentalnej spowiedzi podlega również ten, kto nagrywa za pomoca jakiegokolwiek urządzenia technicznego to, co jest wyznawane w spowiedzi prawdziwej lub symulowanej, własnej lub kogoś innego, lub upowszechnia to za pośrednictwem środków masowego przekazu.

\footnotetext{
${ }^{4}$ Zob. Congregatio pro Doctrina Fidei: Decretum quo, ad Poenitentiae sacramentum tuendum, excommunicatio latae sententiae illi quicumque ea quae a confessario et a poenitente dicuntur vel
} 
$\mathrm{Na}$ temat bezpośredniego naruszenia tajemnicy sakramentalnej mówi także Kodeks Kanonów Kościołów Wschodnich w kan. 1456, bez efektu latae sententiae, mimo iż rozgrzeszenie z grzechu, o którym mowa $\mathrm{w} \S 1$, zarezerwowane jest Stolicy Apostolskiej (kan. $728 \S 1$, nr 1 KKKW).

\section{Rozgrzeszenie osoby będącej wspólnikiem w grzechu przeciw czystości}

Przestępstwa tego nie należy mylić z przestępstwem solicytacji, o którym mowa w kan. 1387. Rozgrzeszenie wspólnika jest bardzo ciężkim przestępstwem popełnionym przez kapłana spowiednika, ponieważ działając jako spowiednik, „rozgrzesza” penitenta z grzechu przeciwko czystości, w którym oboje uczestniczyli. Ciężar tego przestępstwa tkwi w tym, że spowiednik w rzeczywistości oszukuje penitenta wspólnika, że ważnie go rozgrzesza, co nie odpowiada prawdzie, bo tego nie może uczynić, ponieważ nie ma uprawnienia do rozgrzeszenia tego typu grzechu. Jeśli rozgrzeszenie wspólnika w tej materii byłoby ważne, popełnianie tego grzechu mogłoby przekształcić się w rutynę i spowiedź sakramentalna nie służyłaby nawróceniu, lecz zatraceniu. Przestępstwo to stanowią wszystkie grzechy zewnętrzne przeciw czystości (bez konieczności pełnego aktu seksualnego) popełnione ze wspólnikiem, nawet jeśli grzech ten miał miejsce przed przyjęciem święceń.

Oczywiście, trzeba pamiętać, że do popełnienia tego przestępstwa spowiednik musi zdawać sobie sprawę, że spowiadający się jest wspólnikiem w grzechu przeciwko czystości. Jeśli spowiednik nie rozpozna penitenta i go rozgrzeszy, przestępstwo nie zostaje popełnione. Nie ma miejsca przestępstwo także w przypadku, gdy wspólnik jako penitent nie wyznaje grzechu przeciw czystości popełnionego razem ze spowiednikiem, otrzymał bowiem już rozgrzeszenie z tegoż grzechu w sakramentalnej spowiedzi odbytej u innego spowiednika. Roztropność duszpasterska mówi, by nie spowiadać osoby, z którą wcześniej dopuściło się grzechu przeciwko czystości i dla której nie było się przykładem.

Chcąc chronić świętość sakramentu pokuty i pojednania oraz mając na uwadze rzeczywistą poprawę wiernych penitentów, Kościół w swoim prawodawstwie przewidział za popełnienie omawianego przestępstwa karę ekskomuniki. W tej kwestii kan. $1378 \S 1$ (por. kan. 1457 KKKW) stwierdza, że kapłan, który działa wbrew przepisowi kan. 977 - to znaczy usiłuje rozgrzeszyć osobę będącą wspólnikiem w grzechu przeciw szóstemu przykazaniu - podlega ekskomunice latae sententiae, z której uwolnienie jest zastrzeżone Stolicy Apostolskiej, tak jak w poprzednio omawianym przypadku bezpośredniego naruszenia tajemnicy sakramentalnej. Przez termin „Stolica Apostolska” należy rozumieć Kongregację

per instrumenta technica captat vel per communicationis socialis instrumenta evulgat, infertur, AAS 80 (1988), s. 1367; tekst polski w: W trosce o petnię wiary. Dokumenty Kongregacji Nauki Wiary 1966-1994, red. J. Królikowski, Z. Zimowski, Tarnów 1997, t. 2, s. 20. 
Nauki Wiary, która może wymierzyć lub zdeklarować karę ${ }^{5}$, oraz Penitencjarię Apostolską, do której należą decyzje na forum wewnętrznym sakramentalnym i niesakramentalnym.

Warto pamiętać, że odpowiednik § 1 kan. 1378 KPK znajduje się w kan. 1457 KKKW (bez klauzuli latae sententiae) z możliwością rozgrzeszenia tego grzechu wyłącznie przez Stolicę Apostolską (kan. $728 \S 1,2^{\circ}$ KKKW). Pozostałe dwa paragrafy są zestawione w kan. 1443. Rozgrzeszenie wspólnika w grze$\mathrm{chu}, \mathrm{z}$ wyjątkiem niebezpieczeństwa śmierci, jest nieważne także w przypadku wiernych Kościołów Wschodnich, na podstawie kan. 730 KKKW.

Trzeba zauważyć, że zarówno w przypadku bezpośredniego naruszenia tajemnicy sakramentalnej, jak i rozgrzeszenia wspólnika w grzechu, dyspozycje kan. $7291^{\circ}$ i $2^{\circ} \mathrm{KKKW}$, mówią, że jakiekolwiek zastrzeżenia rozgrzeszenia nie mają mocy, jeśli spowiada się osoba chora, która nie może opuścić domu lub nupturient $\mathrm{z}$ okazji sakramentu małżeństwa oraz jeśli spowiednik roztropnie uzna, że nie może zwrócić się o upoważnienie do kompetentnej władzy bez poważnej niedogodności dla penitenta lub bez narażenia na niebezpieczeństwo naruszenia tajemnicy spowiedzi.

Ponadto, w niebezpieczeństwie śmierci każdy kapłan może ważnie i godziwie rozgrzeszyć penitenta $\mathrm{z}$ jakichkolwiek grzechów, także zastrzeżonych (por. kan. $725 \mathrm{KKKW}$ ). Racją tych kanonów jest $\mathrm{z}$ pewnością dobro dusz, najwyższe prawo Kościoła, które nie może ograniczać czy pozbawiać penitenta możliwości uzdrowienia i oczyszczenia w sytuacjach wyjątkowych

\section{Użycie siły fizycznej wobec papieża i konsekracja biskupa bez mandatu papieskiego}

Prawodawca w kan. 1370 § 1 (por. kan. 1445 KKKW, z wyjątkiem kary latae sententiae i w przypadkach bardzo ciężkich; KKKW rozszerza w $\S 2$ przepis $\S 3$ Kodeksu Kościoła łacińskiego, chroniąc osobę świecką „qui actu minus ecclesiasticum exercet”, postanawia, że kto stosuje przymus fizyczny wobec biskupa Rzymu, podlega ekskomunice latae sententiae, mimo iż w praktyce jest to przestępstwo, do którego bardzo rzadko dochodzi w dzisiejszych czasach, podobnie jak konsekrowanie na biskupa bez papieskiego mandatu (kan. 1382 KPK). To drugie przestępstwo polega na udzieleniu wiernemu sakramentu święceń w stopniu episkopatu, bez odpowiedniego zezwolenia papieskiego. Takiego przestępstwa dopuścić się może tylko biskup katolicki w momencie, kiedy udziela święceń biskupich bez zgody papieża. Święcenia takie są ważne, ale nielegalne. Ten, kto udziela święceń, i ten, kto te święcenia przyjmuje, podlega karze ekskomuniki latae sententiae, od której uwolnienie należy zawsze do Stolicy Apostol-

${ }^{5}$ Ioannes Paulus II, Litterae apostolice motu proprio datae Sacramentorum sanctitatis tutela qui bus Normae de gravioribus delictis Congregationi pro Doctrina Fidei reservatis promulgantur, 30.04.2001, AAS 93(2001), s. 737-739; Congregatio pro Doctrina Fidei, Normae de gravioribus delictis, 18.05.2010, AAS 102(2010), s. 419-431, art. 4, n. 1 (dalej: SST). 
skiej, a w przypadku okultyzmu sprawę rozpatruje Penitencjaria Apostolska lub Kongregacja Nauki Wiary, jeśli przestępstwo zostało dokonane publicznie.

W Kodeksie Kanonów Kościołów Wschodnich w kan. 1459 § 1 (bez skutku latae sententiae) mówi się o zezwoleniu władz kompetentnych, a nie o zezwoleniu papieskim, ze względu na procedury związane $\mathrm{z}$ wyborem biskupów w Kościołach patriarchalnych i arcybiskupich większych. Sankcją za to przestępstwo jest ekskomunika większa.

\section{Usiłowanie udzielenia święceń kobiecie}

Należy też przypomnieć o wprowadzeniu do kanonicznych norm nowego przestępstwa, jakim jest usiłowanie udzielenia święceń kobiecie, za które sankcją jest ekskomunika latae sententiae zastrzeżona Stolicy Apostolskiej ${ }^{6}$ - Kongregacji Nauki Wiary w zakresie forum zewnętrznego i Penitencjarii Apostolskiej na forum wewnętrznym. Takie „święcenia” oczywiście są nieważne, a karze podlega zarówno biskup, który usiłuje udzielić święceń, jak i kobieta usiłująca je przyjąć. Jeśli ten, kto usiłuje udzielić święceń, lub kobieta, która święcenia usiłuje przyjąć, należą do Kościoła Wschodniego, podlegają obligatoryjnej karze ekskomuniki większej, z której zwolnienie jest zastrzeżone Stolicy Apostolskiej

\section{SPOWIEDNIK WOBEC WIERNEGO, KTÓRY ZACIACGNĄŁ CENZURE ZAREZERWOWANA STOLICY APOSTOLSKIEJ}

W niniejszym punkcie nakreślony zostanie iter postępowania przez spowiednika, który w trakcie sakramentalnej spowiedzi zorientował się, że ma do czynienia z penitentem, który - na skutek popełnionego jednego z wyżej opisanych przestępstw - popadł w karę cenzury latae sententie zastrzeżonej Stolicy Apostolskiej (na forum wewnętrznym Penitencjarii Apostolskiej).

Spowiednik w takiej sytuacji ma dwie możliwości do wyboru. Pierwsza możliwość: Spowiednik winien wyjaśnić penitentowi jego status kanoniczny, pouczając go jednocześnie o obowiązku wniesienia rekursu celem otrzymania zwolnienia z cenzury. Penitent może sam odwołać się do Penitencjarii Apostolskiej, lecz zazwyczaj czyni to spowiednik, co jest uzasadnione potrzebą ochrony anonimowości penitenta oraz tym, że spowiednik jest w stanie bardziej obiektywnie ocenić całą sprawę i przeprowadzi odwołanie w sposób bardziej kompetentny, niż uczyniłby to penitent. Jeśli zostanie zdecydowany taki sposób działania, wówczas spowiednik powinien ustalić z penitentem spotkanie (miejsce, dzień i godzinę), podczas którego - oczywiście po otrzymaniu uprawnienia z Penitencjarii - będzie mógł zwolnić go z zaciągniętej cenzury i udzielić mu rozgrzesze-

${ }^{6} \mathrm{SST}$, art. 5, nr 1.

${ }^{7}$ Por. SST, art. 5, nr 2. 
nia w rekursie do Penitencjarii Apostolskiej - przedstawiwszy w sposób poufny i bez wskazywania danych osobistych penitenta - należy dobrze przedstawić fakty związane z zaciągnięciem cenzury oraz poprosić o zgodę na rozgrzeszenie wiernego z zaciągniętej cenzury, a także o wskazania dotyczące pokuty, jaka winna być nałożona przez spowiednika na penitenta. Po otrzymanej odpowiedzi z Penitencjarii penitent otrzyma absolucję z cenzury oraz ze swoich grzechów, a także wskazania dotyczące adekwatnej pokuty.

Druga możliwość, z jakiej może skorzystać spowiednik, to posłużenie się przepisem zawartym w kan. 1357 KPK. Norma ta ma wielkie znaczenie w posłudze w konfesjonale. Kanon 1357 § 1 mówi, że spowiednik, w zakresie wewnętrznym sakramentalnym, może zwolnić z cenzury latae sententiae - ekskomuniki interdyktu, wiążących mocą samego prawa, gdy nie zostały orzeczone/ /zdeklarowane publicznie (ale nie z suspensy), jeśli penitentowi jest trudno pozostawać w grzechu ciężkim przez czas konieczny do tego, aby zaradził kompetentny przełożony. Warto także zauważyć, że umorzenie może nastąpić również względem kar zastrzeżonych Stolicy Apostolskiej, a dokonać tego może praktycznie każdy spowiednik. Udzielając zwolnienia z kary, jak czytamy w kan. $1357 \S 2$, „spowiednik powinien nałożyć na penitenta obowiązek odniesienia się w ciągu miesiąca, pod groźbą ponownego popadnięcia w karę, do kompetentnego przełożonego, bądź do kapłana posiadającego odpowiednie uprawnienia [...]. Tymczasem spowiednik powinien nałożyć odpowiednią pokutę i w razie potrzeby nakazać naprawienie zgorszenia i wyrównanie wyrządzonej szkody. Odniesienia może dokonać także spowiednik bez podania nazwiska”.

Penitencjaria, po otrzymaniu rekursu z prośbą o ratyfikację rozgrzeszenia i udzielenia instrukcji odnośnie do meritum sprawy, zbada ją, ratyfikując rozgrzeszenie udzielone przez spowiednika na mocy kan. 1357 KPK i nakładając właściwą pokutę.

\section{NIEPRAWIDŁOWOŚCI}

Nieprawidłowość kanoniczna to materia często nieznana spowiednikom. Nieprawidłowością jest kanoniczny zakaz o charakterze trwałym, który wyklucza możliwość godziwego przyjęcia lub wykonywania święceń już przyjętych, chyba że została udzielona dyspensa przez kompetentną władzę. Nieprawidłowości mogą mieć źródło w przestępstwie, ale nie są one karami kanonicznymi, tak jak na przykład cenzury. Dlatego wierny może być rozgrzeszony z przestępstwa, które popełnił, lub ze wszystkich swoich grzechów, a pozostawać nadal w stanie „nieprawidłowości” aż do momentu uzyskania dyspensy. Nieprawidłowości chronią cześć należną świętym posługom i godność samych posług. Biorąc pod uwagę, że nieprawidłowości nie mają charakteru karnego, ich nieznajomość nie uwalnia od nich osoby (por. kan. $1045 \mathrm{KPK}$ ). 
W świetle obowiązującego prawodawstwa kościelnego Stolicy Apostolskiej (na forum wewnętrznym sumienia Penitencjarii Apostolskiej) zastrzeżone jest dyspensowanie od nieprawidłowości co do przyjęcia lub wykonywania święceń pochodzącej z przestępstwa zabójstwa lub spędzenia płodu, gdy zamierzony cel został osiagnięty (por. kan. 1041, n.4 i 1044, §1, n. 3).

Niestety bardzo częste jest przestępstwo aborcji, o którym mówi kan. 1398KPK: „kto powoduje skutecznie aborcję, podlega ekskomunice latae sententiae". Nie są przestępstwem próby dokonania aborcji bez osiagnnięcia zamierzonego celu, choćby skutek nie nastąpił z przyczyn niezależnych od sprawcy czynu. Poza tym, jeśli nie ma pewności co do osiągnięcia zamierzonego celu, np. jak w przypadku zażycia okazjonalnego pigułki „dzień po”, nie ponosi się kary. Karę ponosi wykonawca aborcji, asystenci, pielęgniarki, nie ponosi jej jednak ten, kto tylko zasugerował czy zachęcał do aborcji (ten ostatni ponosi jedynie bardzo poważną odpowiedzialność moralną). Doradcy i zleceniodawcy, według kan. 1329, podlegają takiej samej karze tylko w przypadku, gdy chodzi o karę ferendae sententiae, tutaj jednak mówimy o latae sententiae. Kara w tym przypadku nie jest zastrzeżona Stolicy Apostolskiej: może być uchylona przez miejscowego lub innego ordynariusza. Podczas spowiedzi może być uchylona przez biskupa, kanonika penitencjarza lub spowiednika, który ma odpowiednie uprawnienia. Ordynariusz miejsca, który dysponuje władzą uwalniania od kar, zgodnie z kan. 1354 § 1 i 2 - może udzielić jej innym.

Kanon 1398 paralelny do kan. $1450 \S 2$ KKKW (bez efektu latae sententiae) odsyła do kan. $728 \S 2$, który odpuszczenie tego grzechu rezerwuje biskupowi eparchialnemu.

Mówiąc o przypadkach zastrzeżonych Stolicy Apostolskiej, trzeba tu jednak uwzględnić przypadek, gdy pozostawanie w grzechu ciężkim jest zbyt trudne dla penitenta, kan. 1357 KPK upoważnia wtedy każdego spowiednika do zwolnienia z cenzury ekskomuniki i interdyktu, gdy nie zostały orzeczone/zdeklarowane publicznie (ale nie z suspensy), przy czym na penitenta należy nałożyć zobowiązanie - pod groźbą ponownego popadnięcia w karę - aby w ciągu miesiąca zwrócił się do kompetentnego przełożonego i zastosował się do jego poleceń. Spowiednicy winni też pamiętać o kanonie 1048 - zakładając spełnienie koniecznych warunków - który pozwala związanym nieprawidłowością na wykonywanie funkcji wynikających w niebezpieczeństwie śmierci, a w przypadku cenzury, która nie została orzeczona, także dla dobra innych wiernych, którzy poproszą, na sprawowanie sakramentów, sakramentaliów lub władzy rządzenia.

Gdy chodzi o prośbę o dyspensę od nieprawidłowości, np. do przyjęcia czy wykonywania władzy święceń, to kierowana ona jest do Penitencjarii Apostolskiej w formie listu przez spowiednika, kierownika duchowego osoby dotkniętej nieprawidłowością lub innego przełożonego, do którego zwróciła się osoba zainteresowana. Ponieważ sprawa jest rozpatrywana na forum wewnętrznym (sakra- 
mentalnym lub pozasakramentalnym), należy pominąc dane personalne osoby, opisując wyczerpująco fakty i zdarzenia, które były powodem nieprawidłowości. W przypadku kandydata do święceń należy także podkreślić, czy kandydat, w ocenie piszącego spowiednika czy ojca duchownego, jest zdolny do przyjęcia sakramentu. Istotna jest także wzmianka o autentycznym nawróceniu kandydata i jego żarliwości na drodze ku kapłaństwu.

\section{INNE MATERIE ROZPATRYWANE NA FORUM WEWNĘTRZNYM PRZEZ PENITENCJARIE APOSTOLSKA}

Do Penitencjarii Apostolskiej można odwoływać się także w sprawach, które nie są zastrzeżone Stolicy Apostolskiej. Ten bowiem Trybunał Apostolski, będący Trybunałem Miłosierdzia i Łaski, jest kompetentny nie tylko w materii karnej i administracyjnej, wcześniej omówionej, oczywiście na forum wewnętrznym zarówno sakramentalnym, jak i pozasakramentalnym, lecz w ogóle we wszystkim, co jest pożyteczne dla sumień wiernych należących do jakiegokolwiek obrządku i co jest związane z udzieleniem „,ask”, „absolucji”, „dyspens” „sanacji”, „zamian” i „zwolnień”, a także w badaniu i rozstrzyganiu problemów sumienia. Prosząc o łaski, sanacje, dyspensy itp., trzeba zawsze pamiętać, że Penitencjaria Apostolska może na forum wewnętrznym udzielić prawie wszystkiego, czego na forum zewnętrznym udzielają inne dykasterie Stolicy Apostolskiej, o ile oczywiście to, o co się prosi, jest możliwe do rozwiązania na forum wewnętrznym.

Godne uwagi są pewne przypadki, które mogą być rozpatrywane przez Penitencjarię Apostolską, a mianowicie: uważnieniew związku małżeństw zawartych nieważnie czy wątpliwości co do ważności sakramentów chrztu, bierzmowania i święceń, zobowiązania mszalne, jak również rozmaite kwestie o charakterze moralnym, etycznym i kanonicznym.

\section{Uważnienie w związku małżeństw nieważnych z powodu przeszkód tajnych}

Penitencjaria Apostolska może udzielić tej łaski, kiedy z uzasadnionych powodów byłoby słuszne uczynienie tego na forum wewnętrznym. Takim słusznym powodem może być ochrona dobra osobistego małżonków. Dokonując sanacji na forum wewnętrznym, uważnia się małżeństwo uważane przez daną społeczność za ważne. Oczywiście taka sanacja na forum wewnętrznym może mieć miejsce, jeśli nie istnieją przeszkody, o których mowa w prawie kanonicznym, do ważnego zawarcia związku małżeńskiego, jak np. uprzedni ważnie zawarty związek jednej czy obu stron.

Zanim podejmie się decyzję co do uważnienia w związku, trzeba zweryfikować, czy istnieje prawdziwa wola małżeńska, z której można domniemywać, że strony chcą kontynuować swoje wspólne życie. Kompetentną władzą do uważ- 
nienia małżeństwa w związku jest biskup diecezjalny, lecz z uzasadnionych racji wierni mogą odnieść się także do Stolicy Apostolskiej. Prośba o uważnienie może być złożona przez obie strony lub przez jedną z nich, nawet bez wiedzy drugiej. Kapłan, który otrzymał decyzję o uważnieniu w zawiązku małżeństwa poprzez reskrypt Penitencjarii Apostolskiej, winien dołączyć dane obydwóch osób do tego reskryptu i zdeponować go w tajnym archiwum kurii diecezjalnej. Jest stosowne, aby zabiegający o uważnienie zachowali numer protokołu tego reskryptu na wypadek, gdyby było konieczne udowodnienie zaistniałej sanacji w przyszłości. Jeśli kapłan otrzymał informację o nieważności małżeństwa w trakcie spowiedzi sakramentalnej, wówczas reskrypt Penitencjarii Apostolskiej należy zniszczyć, po zakomunikowaniu jego treści petentowi (petentom) i podaniu im numeru protokołu, by go mieli jako dowód otrzymanego uważnienia. Można też odwoływać się do Penitencjarii Apostolskiej, gdy z jakiegoś powodu, który pozostaje tajny, istnieje u kogoś wątpliwość co do ważności sakramentów chrztu, bierzmowania i święceń (takie wątpliwości rodzą się u niektórych osób, na skutek np. braku koncentracji czy niepewności co do użytej materii czy formy przy sprawowaniu sakramentu itd.). Penitencjaria bada konkretny przypadek i odpowiada zainteresowanemu, autoryzując ponowienie rytu sakramentalnego sub conditione lub absolute, lub też po prostu odpowiada się, że dany sakrament jest ważny i nie należy mieć więcej wątpliwości w tej sprawie.

\section{Zobowiązania mszalne ciążące na kapłanach na skutek przyjętych stypendiów mszalnych}

Chociaż zobowiązania mszalne nie są obwarowane żadną cenzurą, wydaje się rzeczą pożyteczną zwrócić na nie uwagę, gdyż mają wielkie znaczenie w życiu Kościoła. Wiążą się bowiem zarówno ze czcią Najświętszego Sakramentu Eucharystii, jak i obowiązkami wypływającymi ze sprawiedliwości. Mogą też wydatnie wzmagać albo - przeciwnie - osłabiać zaufanie wiernych, jakie okazują oni swoim kapłanom. Dlatego też trzeba pamiętać o zachowywaniu norm zawartych w kanonach 945-958 KPK i kan. 717 KKKW. Doświadczenie bowiem poucza, że są kapłani, którzy niekiedy zwalniają się z wypełniania tych zobowiązań, błędnie rozumiejąc, iż przeznaczenie stypendium na jakiś dobry cel zadośćuczyni przyjętemu zobowiązaniu bez odprawiania Mszy św. ad mentem offerentis. Na mocy obowiązku wypływającego ze sprawiedliwości oprócz kanonów wyżej wymienionych należy także zachować Dekret Kongregacji do spraw Duchowieństwa, zatwierdzony przez papieża Jana Pawła II „w sposób specjalny” dnia 22 stycznia 1991 roku i ogłoszony 22 lutego 1991 roku, gdzie mówi się o problemie łączenia razem wielu intencji, tzw. kumulacji.

Jeżeli kapłan przyjął określoną liczbę intencji mszalnych i nie jest w stanie ich odprawić, może na forum wewnętrznym za pośrednictwem swojego spowiednika, odwołać się do Penitencjarii Apostolskiej, która ma kompetencje w tych 
sprawach, z prośbą o sanacje, redukcje lub inne jeszcze środki. W przypadku, w którym obowiązek odprawienia Mszy spoczywa na osobie prawnej lub instytucji, na przykład na seminarium lub kurii diecezjalnej, Penitencjaria nie ma kompetencji, by takiego rodzaju łaski udzielić. Kompetencje wobec tych instytucji na forum zewnętrznym ma Kongregacja do spraw Duchowieństwa.

Spowiednik, występując do Penitencjarii Apostolskiej w imieniu kapłana-penitenta, pomijając jego dane osobiste (imię i nazwisko) winien w reskrypcie dokładnie określić - jeśli to możliwe - liczbę mszy świętych nieodprawionych wraz z przybliżonym wiekiem penitenta, a także podać przyczyny, ze względu na które nie zostały odprawione, oraz co uczynił z pieniędzmi przyjętymi za nie. Ponadto nie może zabraknąć informacji o stanie zdrowia kapłana-penitenta i o liczbie mszy świętych, które byłby w stanie jeszcze odprawić osobiście lub powierzyć innemu kapłanowi czy kapłanom współbraciom diecezjalnym lub zakonnym.

Penitencjaria, po otrzymaniu takowego rekursu, oceni informacje w nim zawarte i podejmuje stosowną decyzję, którą może być - w przypadku bardzo słabego stanu zdrowia i zaawansowanego wieku - dyspensa od zobowiązań przyjętych albo też redukcja mszy świętych, które nie zostały odprawione przez wspomnianego kapłana, nakładając obowiązek odprawienia lub zlecenia odprawienia innym mniejszej liczby mszy świętych, a resztę zaczerpnie z tzw. „skarbca Kościoła"8. O każdej redukcji zobowiązań mszalnych kardynał penitencjarz większy jest zobowiązany powiadomić Ojca Świętego na prywatnych audiencjach.

\section{Rozmaite kwestie o charakterze moralnym, etycznym i kanonicznym absorbujące ludzkie sumienie}

Kapłani mogą swobodnie odwoływać się do tej posługi spełnianej przez Penitencjarię, gdy podczas wypełniania swych zadań spotkali przypadki trudne do rozstrzygnięcia. Chodzi o kwestie o charakterze moralnym, etycznym czy kanonicznym. To odwołanie może być tym bardziej wskazane, że niekiedy, mimo obfitej literatury teologicznej, u wielu pisarzy występuje godne ubolewania pomieszanie pojęć i wcale nie jest nierealne niebezpieczeństwo przyjęcia za prawdziwą naukę i za dozwolony sposób postępowania tego, co głoszą autorzy pozostający w sprzeczności z Magisterium Kościoła.

Należy jednak zwrócić uwagę, że odpowiedzi Penitencjarii dotyczące spraw sumienia mają moc wiążąca jedynie wobec tych realnych i konkretnych sytuacji,

\footnotetext{
${ }^{8}$ Wyrażenie „skarbiec Kościoła” należy rozumieć nie jako nagromadzenie dóbr materialnych, które posiada Kościół, ale jako nieskończoną i niewyczerpaną wartość, którą mają przed Bogiem zadośćuczynienia i zasługi naszego Pana Jezusa Chrystusa, do których dochodzi także ogromna wartość, którą mają wobec Boga modlitwy i dobre dzieła Najświętszej Dziewicy Maryi i wszystkich świętych (por. Clemente VI, Bulla unigenitus Dei Filus, w: Paolo VI, Const. Apost. Indulgentiarum doctrina).
} 
dla których zostały dane. Wobec innych przypadków mogą stanowić jedynie wskazówkę i żadną miarą nie wolno ich publicznie rozgłaszać. Trzeba następnie zaznaczyć, że zagadnienia ogólne, mające formę pytań czysto teoretycznych, należy kierować nie do Penitencjarii Apostolskiej, lecz odpowiednio do ich charakteru albo do Kongregacji Nauki Wiary (problemy doktrynalne), albo do innych dykasterii Stolicy Apostolskiej.

Można to zilustrować przykładem. Mamy pytanie czysto teoretyczne: Czy wolno zawrzeć małżeństwo osobie dotkniętej dziedziczną chorobą? Należy takie pytanie skierować do Kongregacji Nauki Wiary. Inny przykład - mamy pytanie konkretne: Czy osoba N, dotknięta określoną chorobą, może zawrzeć małżeństwo? Gdy przypadek jest jawny, również należy skierować pytanie do tejże Kongregacji. Do Penitencjarii natomiast kieruje się to konkretne pytanie wtedy, gdy przypadek jest tajny.

Penitencjaria Apostolska każdy konkretny przypadek przedłożony jej skrzętnie studiuje, konsultując ze swoimi specjalistami, i daje odpowiedź w sprawie. Odpowiedź na konkretną kwestię, tak jak zostało to już podkreślone, ma moc wiążąca jedynie wobec realnej i konkretnej sytuacji, dla której została dana. Wobec innych przypadków może być jedynie wskazówką i żadną miarą nie wolno jej publikować.

\section{ODPUSTY}

Do kompetencji Penitencjarii Apostolskiej należą także sprawy związane z udzielaniem i praktyką odpustów, z wyjątkiem kwestii dogmatycznej tych odpustów, które w tym przypadku zarezerwowane są Kongregacji Nauki Wiary.

W historii narosło wiele opinii na temat odpustów. Były czasy, w których poprzez niewłaściwe ich traktowanie dochodziło do bardzo poważnych nadużyć. Dzisiaj, a już właściwie podczas trwania Soboru Watykańskiego II, zorientowano się, że odpusty są zbyt ważną sprawą, by przejść obok nich obojętnie. Z tej racji Paweł VI ogłosił w Konstytucji apostolskiej Indulgentiarum doctrina, z dniem 1 stycznia 1967 roku, poprawioną naukę w zakresie praktyki odpustów. Podaje ją w sposób skondensowany w kanonach 992-997 Kodeks Prawa Kanonicznego Jana Pawła II z 1983 roku.

Wspomniany Kodeks Prawa kanonicznego w kan. 992 zawiera następującą definicję odpustu: „Odpust jest to darowanie przed Bogiem kary doczesnej za grzechy, odpuszczone już co do winy. Otrzymuje je wierny, odpowiednio przygotowany i po wypełnieniu pewnych określonych warunków, przez działanie Kościoła, który jako sługa odkupienia autorytatywnie rozporządza i dysponuje skarbcem zadośćuczynień Chrystusa i świętych".

Chrześcijanin skruszony w swoim sercu i żałujący szczerze za popełnione grzechy w sakramencie pokuty otrzymuje odpuszczenie winy, natomiast pozo- 
staje jeszcze tzw. kara doczesna. Darowanie kary doczesnej określa się terminem „odpust”, którego uzyskanie zakłada szczerą wewnętrzną przemianę oraz wypełnienie przepisanych uczynków.

Odpust jest cząstkowy lub zupełny, w zależności od tego, czy uwalnia od kary doczesnej należnej za grzechy w części lub całości. Paweł VI zniósł odpusty określane konkretnym czasem (np. ilością dni lub lat), ponieważ w wieczności nie ma czasu. Ten, kto jest ochrzczony, nie jest ekskomunikowany i znajduje się w stanie łaski uświęcającej, przynajmniej pod koniec wypełniania przepisanych czynności jest zdolny do uzyskania odpustu.

Wierny może uzyskiwać odpust zupełny lub cząstkowy tylko za siebie lub ofiarować go za zmarłego, na sposób wstawienniczy, ale za nikogo z żyjących, ponieważ każdy człowiek sam jest w stanie dokonać przemiany swojego życia i wypełnić wymagane do otrzymania odpustu warunki.

Odpust zupełny można uzyskać tylko jeden raz w ciagu dnia, poza pozostającymi w obliczu śmierci, natomiast odpusty cząstkowe można uzyskiwać w ciągu jednego dnia wielokrotnie.

Wierny może dostąpić odpustu zupełnego, który znosi wszystkie kary doczesne należne za grzech odpuszczony co do winy w sakramencie pokuty. Warunkiem dostąpienia tej łaski jest przystąpienie do sakramentu pojednania i Komunii św., całkowicie wewnętrzne oderwanie się od grzechu, nawet najlżejszego, spełnienie czynu, z którym związany jest odpust zupełny, oraz modlitwa w intencjach Ojca Świętego.

Przyjrzyjmy się bliżej tym wspomnianym warunkom.

1. Spowiedź sakramentalna - nie można zyskać odpustu bez odbycia spowiedzi sakramentalnej. Powinna ona mieć miejsce na kilka dni przed lub po wypełnieniu czynności odpustowej (na kilka, tzn. zaleca się trzymanie się granicy 8 dni przed i po); istnieje także zasada, że po jednej spowiedzi sakramentalnej można uzyskać wiele odpustów zupełnych, ale tylko jeden w ciagu jednego dnia!

2. Komunia eucharystyczna - to kolejny niezbędny do zyskania odpustu zupełnego warunek; można ją przyjąć pod jedną z dwóch postaci, a więc albo chleba, albo wina, lub pod dwiema, czyli chleba $\mathrm{i}$ wina, w przeddzień dopełnienia czynu obdarzonego odpustem i w ciagu siedmiu dni po dopełnieniu czynności odpustowych; jednak zaleca się, aby Komunię św. przyjąć w dniu, w którym pragnie się dostąpić łaski odpustu, gdyż zwiększa to możliwość jego zyskania. Należy także zaznaczyć, że w odróżnieniu od spowiedzi po przyjęciu jednej Komunii św. można uzyskać tylko jeden odpust zupełny! Wyjątek od tej reguły stanowi niebezpieczeństwo śmierci.

3. Modlitwa $\mathbf{w}$ intencjach papieża, czyli w intencjach wyznaczonych przez Ojca Świętego. Wierny nie musi ich znać, wystarczy, że wzbudzi ogólną intencję modlitwy w wyznaczonych przez papieża intencjach; odmówienie tej modlitwy może mieć miejsce $\mathrm{w}$ ciągu kilku dni przed wykonaniem dzieła odpustowego lub 
po nim, ale podobnie jak w przypadku Komunii Świętej zaleca się, aby modlitwa została odmówiona w dniu wykonania czynu odpustowego. Jakie to mają być modlitwy? Dla wypełnienia warunku wystarcza jedno Ojcze nasz i jedno Zdrowaś Maryjo. Pozostaje jeszcze kwestia jak, tzn. modlić się ustnie czy tylko w myśli? Ogólna reguła głosi, że ma to być modlitwa ustna, a dla zyskania odpustu zupełnego wystarczy odmówić tę modlitwę na przemian z kimś innym lub śledzić ją swoją myśla, gdy ktoś inny tę modlitwę odmawia głośno.

4. Calkowite wykluczenie przywiązania do jakiegokolwiek grzechu, także powszedniego - jest to ostatni warunek konieczny do zyskania odpustu zupełnego, ostatni i bardzo trudny do wypełnienia, ale możliwy. Kiedy mamy do czynienia z przywiązaniem do grzechu? Mówimy o nim wtedy, gdy ktoś świadomie grzeszy więcej niż raz, znaczy to, że grzeszy i chce tego, a przy tym nie poprzestaje na jednym grzechu, ale dopuszcza do pewnej wielokrotności, jakkolwiek nie do zwyczaju, z którego rodzi się nawyk.

Odpust zupełny może zyskać tylko ten, kto nie jest przywiązany do grzechu lekkiego, np. do spóźniania się na mszę św. (bo na pociąg do pracy czy do szkoły się nie spóźnia!). To przywiązanie do grzechu jest zawinione i jako takie stanowi przeszkodę do uzyskania odpustu (bo jak wiadomo odpust nie gładzi grzechu - w tym celu konieczna jest spowiedź). W tym przypadku chodzi o szczere nastawienie umysłu i woli, aby spełnić wolę Bożą także w szczegółach, i o jej umiłowanie, przy równoczesnym odwróceniu się od nieuporządkowanych relacji ze światem i samym sobą.

Trudność wyzbycia się przywiązania do jakiegokolwiek grzechu można więc porównać z trudnością wzbudzenia w sobie żalu doskonałego. Jednak tak wzbudzenie aktu żalu, jak i uzyskanie odpustu zupełnego jest możliwe, należy tylko jak najpełniej otworzyć się na działanie Bożych łask w swoim codziennym życiu. Tylko bowiem mocą Bożego miłosierdzia możemy się nawracać i zadośćuczynić za swoje grzechy i zmarłych cierpiących w czyśćcu. Głębokie i szczere pragnienie zyskania odpustu, zawierzenie się łasce Bożej oraz wypełnienie, z pełnym zaangażowaniem woli i serca, wszystkich warunków z pewnością jest w stanie wytworzyć w nas odpowiednią dyspozycję do otwarcia się na dar odpustu zupełnego.

Gdy chodzi o aspekt praktyczny składania prośby o uzyskanie odpustu, z racji różnych okazji przedkłada się je na piśmie, podając motyw, i dołączając na końcu zatwierdzenie przez kompetentną władzę kościelną. Z terenów misyjnych zazwyczaj takowe prośby wpływają za pośrednictwem nuncjuszy apostolskich. W ostatnich latach bardzo wzrosła liczba próśb o odpusty; to znak otwarcia na Miłosierdzie Boże. Penitencjaria Apostolska na mocy władzy udzielonej jej przez Ojca Świętego chętnie udziela ze Skarbca Kościoła daru odpustów. Aby wyjść naprzeciw wszystkim prośbom o odpusty, sugeruje się wysyłanie ich przez osoby zainteresowane $\mathrm{z}$ wystarczającym wyprzedzeniem. Tylko w ten sposób dekret zostanie przesłany w stosownym czasie. 


\section{ZAKOŃCZENIE}

Niniejsze opracowanie jest próbą przedstawienia najstarszej Dykasterii Kurii Rzymskiej, jaką jest Penitencjaria Apostolska, jej struktury, kompetencji, działalności oraz zarówno metody jej codziennej pracy, jak i sposobu traktowania spraw sumienia, które z racji swego ciężaru są zarezerwowane dla Stolicy Apostolskiej.

Podkreślono, że jest ona Trybunałem Miłosierdzia w służbie Kościołowi i że na podstawie doświadczeń wieków historii Kościoła można dowieść, że wszystko to, co stanowi forum wewnętrzne w Kościele, ma niezgłębioną wartość. Misją Kościoła jest zbawienie dusz. W tę misję w sposób jakże szczególny włącza się Trybunał Penitencjarii Apostolskiej. Dobrze jest więc, że istnieje taki trybunał miłosierdzia Bożego i że służy wiernym w ich drodze pojednania $\mathrm{z}$ Bogiem. Trybunał ten był i jest na co dzień świadkiem wielu nawróceń. Penitencjaria jest dumna z możliwości wykonywania tej posługi, pamiętając o słowach wypowiedzianych przez Zbawiciela: „Będzie większa radość w niebie z jednego grzesznika, który się nawraca, niż z dziewięćdziesięciu dziewięciu sprawiedliwych, którzy nie potrzebują nawrócenia" (Łk 15,7).

Penitencjaria nie ukrywa przestępstw, ale działając na forum wewnętrznym i rozpatrując sprawy ludzkiego sumienia i ludzkiej słabości, zdaje sobie sprawę z otrzymanej misji jednania człowieka z Bogiem i Kościołem, nie zapominając o podstawowej prawdzie, że wiara oparta jest na prawdzie objawienia Pańskiego, a nie na osobach w Kościele. Kościół tworzą grzesznicy, ale jego Założyciel jest święty, jego doktryna jest święta i wzywa nas do życia w świętości.

\section{SUMMARY}

In this paper the author, the Regent of the Apostolic Penitentiary, has illustrated the oldest Dicastery of the Roman Curia, which is the Apostolic Penitentiary, its structure, competency, activities and the method of its daily work, as well as the treatment of cases of conscience which, because of their gravity, are reserved to the Apostolic See.

It was pointed out that it is the Tribunal of Mercy at the service of the Church, and that based on the experience of centuries of Church history, it can be proven that everything pertaining to the internal forum in the Church is of inestimable value. The mission of the Church is the salvation of souls. In this mission the Tribunal of the Apostolic Penitentiary enters in a most special way. It is therefore good that such a Tribunal of Divine Mercy exists, and that it serves the faithful on their way of reconciliation with God. This Tribunal was and is a daily witness to so many conversions. The Penitentiary is proud of the possibility of carrying out this service, mindful of the words spoken by the Savior: „There will be more joy in heaven over one sinner who repents than over the ninetynine righteous persons who need no conversion (Luke 15: 7). The Penitentiary does not hide transgressions, but acting in the internal forum and examining matters of human conscience and weakness, is aware of the mission received of reconciliation with God and the Church, not forgetting the fundamental truth that faith is based on the truth of the Revelation of the Lord, and 
not on the people in the Church. The Church is made up of sinners, but its Founder is holy, his doctrine is holy and calls us to a life of holiness.

\section{Keywords}

Tribunal of mercy, internal forum, external forum, conscience, sin, transgression, latae sententiae censure and sins reserved to the Apostolic See, confessor, irregularity, indulgences

\section{BIBLIOGRAFIA}

\section{Źródla prawa}

Clemens VI, Bulla iubilaei unigenitus Dei Filus, 27 ian. 1343, in D-SCh 1025-1027: Extravagantes comunes, 5, 9, 2.

Paulus VI, Const. Apost. Indulgentiarum doctrina, (1.01.1967), „Acta Apostolicae Sedis” 59 (1967) 5-24.

Ioannes Paulus II, Const. Apost. de Romana Curia „Pastor Bonus”, (28.06.1988), „Acta Apostolicae Sedis" 80 (1988), s. 841-934.

Ioannes Paulus II, Codex Iuris Canonici Ioannis Pauli PP.II auctoritate promulgatus, 25.01. 1983, „Acta Apostolicae Sedis” 75/II (1983) 1-317.

Ioannes Paulus II, Fidei Depositum qua Catholicae Ecclesiae Catechismus post Concilium Oecumenicum Vaticanum II instauratus publici iuris fit, (11.10.1992), „Acta Apostolicae Sedis" 86 (1994) 113-118.

Ioannes Paulus II, Bulla Incarnationis mysterium, (29.11.1998), „Acta Apostolicae Sedis” 91/II (1999) 29-147.

Ioannes Paulus II, Il Sacramento della Penitenza Nei messaggi del Sommo Pontefice Giovanni Paolo II alla Penitenzieria Apostolica, Libreria Editrice Vaticana 2000.

Ioannes Paulus II, Litt. Apost. motu proprio datae „Sacramentorum sanctitatis tutela” quibus Normae de gravioribus delictis Congregationi pro Doctrina Fidei reservatis promulgantur (30.04.2001), „Acta Apostolicae Sedis” 93 (2001), s. 737-739.

Ioannes Paulus II, Litt. Apost. motu proprio datae quibus normae quaedam inseruntur in Codice Iuris Canonici et in Codice Canonum Ecclesiarum Orientalium „Ad tuendam fidem” (18.05.1998), „Acta Apostolicae Sedis” 90 (1998), s. 457-461.

Benedictus PP. XVI, Allocutio ad Sacrae Rotae Romanae Tribunal, occasione inaugurationis Anni Iudicialis (21.01.2012), „Acta Apostolicae Sedis” 104 (2012), s. 103-107.

Pontificium Consilium de Legum Textibus Interpretandis, Responsio ad propositum dubium (4.06.1999), „Acta Apostolicae Sedis” 91 (1999), s. 918.

Concilium Oecumenicum Vaticanum II, Constitutio dogmatica de Ecclesia „Lumen gentium”, „Acta Apostolicae Sedis” 57 (1965), s. 5-75.

Regolamento Generale della Curia Romana, Libreria Editrice Vaticana 1999. 
Congregatio pro Doctrina Fidei, Normae de gravioribus delictis (18.05.2010), „Acta Apostolicae Sedis" 102 (2010), s. 419-431.

Congregatio pro Doctrina Fidei, Decretum quo, ad Poenitentiae sacramentum tuendum, excommunicatio latae sententiae illi quicumque ea quae a confessario et a poenitente dicuntur vel per instrumenta technica captat vel per communicationis socialis instrumenta evulgat, infertur, „Acta Apostolicae Sedis” 80 (1988), s. 1367; tekst polski w: W trosce o petnie wiary. Dokumenty Kongregacji Nauki Wiary 1966-1994, red. J. Królikowski, Z. Zimowski, t. 2, Tarnów 1997, s. 20.

Congregatio pro Doctrina Fidei: Professio fidei et Iusiurandum fidelitatis in suscipiendo officio nomine Ecclesie exercendo una cum nota doctrinali adnexa (29.06.1998), ,Acta Apostolicae Sedis" 90 (1998), s. 542-551.

Paenitentiaria Apostolica, Enchiridion indulgentiarum. Normae et concessiones, Libreria Editrice Vaticana $1999^{4}$; tlumaczenie wloskie: Manuale delle indulgenze. Norme e concessioni, Libreria Editrice Vaticana $1999^{4}$

Reskrypt ex Audientia SS.mi, Watykan 16 czerwca 2005

\section{LITERATURA}

Maggiolini S., Peccato e perdono nella Chiesa, Brescia 1969.

Pinto P., Commento al Codice di Diritto Canonico, Roma 1985.

Calabrese A., Diritto penale canonico, Roma 1996.

Codice di Diritto Canonico commento, Milano 2001.

De Bertolis O., L'atto di defezione dalla Chiesa, „La civiltà cattolica” 2007, nr 4, s. 125$-138$.

De Bertolis O., L'ellisse giuridica, Padova 2011.

De Paolis, V., Apostata, w:Nuovo Dizionario di diritto canonico, ed. C. Corral Salvador, V. De Paolis, G. Ghirlanda, Cinisello Balsamo 1993, s. 34-35.

De Paolis, V., Appartenenza alla Chiesa, w:Nuovo Dizionario di diritto canonico, ed. C. Corral Salvador, V. De Paolis, G. Ghirlanda, Cinisello Balsamo 1993, s. 37-42.

De Paolis, V., Scismatico, w:Nuovo Dizionario di diritto canonico, ed. C. Corral Salvador, V. De Paolis, G. Ghirlanda, Cinisello Balsamo 1993, s. 958-959.

De Paolis, V., Scomunica, w:Nuovo Dizionario di diritto canonico, ed. C. Corral Salvador, V. De Paolis, G. Ghirlanda, Cinisello Balsamo 1993, s. 959-962. 